\title{
PERANCANGAN SISTEM INFORMASI PENGELOLAHAN DATA PENJUALAN KARET PADA PT. BUMI BELITI ABADI BERBASIS WEB MOBILE
}

\author{
Davit Irawan ${ }^{1 *}$, Lukman Sunardi $^{2}$ \\ Program Studi Informatika, Universitas Bina Insan, Lubuklinggau ${ }^{1,2}$ \\ Email : davit_irawan@univbinainsan.ac.id ${ }^{1}$, lukman_sunardi@univbinansan.ac.id ${ }^{2}$
}

\begin{abstract}
Abstrak
PT. Bumi Beliti Abadi memberikan kemudahaan kepada petani karet untuk dapat menjual hasil produk karet mereka, petani karet akan mendapat harga sesuai dengan pasaran jika menjual hasil karet mereka kepada perusahaan ini, namun pada kenyataan nya dalam proses pengolahan datanya seperti rekap data pencatatan transaksi penjualan dan pembelian hasil karet, data distributor, data karet yang telah dikelola menjadi karet mentah, data pelanggan, dan lain sebagainya masih juga dilakukan pendataan menggunakan aplikasi Microsoft excel, hal tersebut berdampak pada dokumentasi transaksi yang belum terintegrasi dengan baik karena tidak dilakukan pendataan menggunakan sistem komputer. Tujuan dari penelitian ini ialah untuk membuat sistem yang baru yang diharapkan dapat membantu proses pengelolahan data karet. Sistem yang baru ini dibangun dengan aplikasi berbasis Web Mobile, yang mana dengan aplikasi ini diharapkan dapat mengatasi permasalahan pengelolahan data karet yang selama ini terjadi di PT. Bumi Beliti Abadi yang dinilai lambat. Penelitian ini menggunakan metode pengembangan sistem dengan metode Waterfall, dimana pengerjaan dari suatu sistem dilakukan secara berurutan atau secara linear yang dimulai dari analisis kebutuhan, desain sistem, penulisan kode program, pengujian program dan implementasi sistem tersebut. Hasil dari penelitian ini sistem dapat memberikan kemudahana bagi pihak PT Bumi Beliti Abadi dalam melakukan pengolahan data harga karet, penjualan, pembelian dan data produksi karet serta laporan sistem akan menampilkan statistik data hasil dari pengolahan data penjualan, pembelian dan produksi karet secara update.
\end{abstract}

Kata Kunci : Sistem Informasi; Karet; Web Mobile; Waterfall

\begin{abstract}
PT. Bumi Beliti Abadi makes it easy for rubber farmers to be able to sell their rubber products, rubber farmers will get a price according to the market if they sell their rubber products to this company, but in fact, in the data processing process, such as data recapitulation of sales and purchase transactions of rubber products, distributor data, rubber data that has been managed into raw rubber, customer data, etc., data collection is still carried out using Microsoft Excel, this has an impact on transaction documentation that has not been properly integrated because data is not collected using a computer system. The purpose of this research is to create a new system which is expected to help the rubber data processing process. This new system is built with a Web Mobile based application, which with this application is expected to be able to solve the rubber data processing problems that have been occurring at PT. Bumi Beliti Abadi which is considered slow. This study uses a system development method with the Waterfall method, where the work of a system is carried out sequentially or linearly starting from needs analysis, system design, writing program code, testing the program and implementing the system. The results of this study, the system can provide convenience for PT Bumi Beliti Abadi in processing rubber price data, sales, purchases and rubber production data and the system report will display statistical data results from processing sales, purchasing and production of rubber in an updated manner.
\end{abstract}

Keywords: Information Systems; Rubber; Web Mobile; Waterfall 
I PENDAHULUAN

PT. Bumi Beliti Abadi merupakan salah satu usaha perusahaan yang membeli serta menjual karet yang yang telah dikelola, perusahaan ini berada di Desa Remayu, Tuah Negeri, Kabupaten Musi Rawas, Provinsi Sumatera Selatan. Keberadaan PT. Bumi Beliti Abadi di desa Remayu memberikan kemudahaan kepada petani karet untuk dapat menjual hasil produk karet mereka. Petani karet akan mendapat harga sesuai dengan pasaran jika menjual hasil karet mereka kepada perusahaan ini.

Perancangan merupakan cara yang digunakan untuk membangun sebuah sistem informasi sehingga dapat mempermudah suatu pekerjaan dan dapat berjalan dengan lebih efektif dan efisien serta dengan adanya perancangan juga dapat mengetahui kekurangan sistem informasi sehingga dapat dilakukan perbaikan dan pengembangan sistem [1], dengan adanya perancangan yang dilakukan dapat lebih memudahkan dan mempercepat proses dari suatu sistem informasi sehingga dapat menghasilkan data yang efektif dan efisian dan memiminamlisir kesalahan dalam suatu proses sistem informasi [2].

Sistem Informasi adalah kombinasi dari teknologi informasi dan aktivitas orang yang menggunakan teknologi itu untuk mendukung informasi dan manajemen, dengan adanya suatu sistem informasi berbasis web dapat mempermudah dalam penyampaian informasi mengenai data-data yang ada pada website [3]. Sistem informasi dapat menampilkan serta menunjukan sebuah informasi yang diperlukan dan dibutuhkan oleh masyarakat, dengan adanya sistem informasi ini informasi yang dihasilkan dapat lebih akurat dan efsien sehingga dapat menghemat waktu, tenaga dan biaya, sistem informasi dapat bersifat mobile sehingga dapat digunakan oleh banyak penduduk [4].
Berdasarkan hasil dari penelitian ini alur dari proses penjualan karet diketahui ada tiga saluran pada rantai penjualan yakni saluran satu terdiri dari Pekebun Saluran 1 (PS1), Pengumpul Desa Saluran 1(PDS1), Pengumpul Kecamatan Saluran 1 (PKS1) dan Pabrik Pengolah Bokar (PPB), saluran dua terdiri dari Pekebun Saluran 2 (PS2) Pengumpul Desa/Kecamatan Saluran 2 (PDKS2) (PKS1) dan Pabrik Pengolah Bokar (PPB), untuk saluran tiga yakni Pekebun Saluran 3 (PS3) UPPB (UP) dan Pabrik Pengolah Bokar (PPB) [5].

Setiap karet yang telah ditimbang oleh petugas selanjutnya dicatat pada nota pembelian untuk diberikan kepada petani, pengumpul karet dan UPPB dan dicatat pada buku transaksi pembelian, data transaksi tersebut akan direkap di Microsoft excel oleh operator timbangan. Hasil perekapan tersebut diberikan ke bagian keuangan dan selanjutnya bagian keuangan mengeluarkan uang sebesar jumlah pembelian dan mencatat jumlah pengeluaran tersebut pada saat pembuatan laporan, pengolahan data lainnya seperti rekap data pencatatan transaksi penjualan dan pembelian hasil karet, data distributor, data karet yang telah dikelola menjadi karet mentah, data pelanggan, dan lain sebagainya masih juga dilakukan pendataan menggunakan aplikasi Microsoft excel, Hal tersebut berdampak pada dokumentasi transaksi belum terintegrasi dengan baik karena tidak dilakukan pendataan menggunakan sistem komputer, dengan proses pendataan tersebut menyebabkan timbulnya berbagai permasalahan seperti, sulitnya mencari data transaksi ataupun pembuatan laporan transaksi karena harus dibuat dengan merekap data-data transaksi tersebut serta proses transaksi yang lama karena transaksi harus dihitung menggunakan aplikasi Microsoft excel serta sering terjadinya kesalahan dalam proses rekap data, serta 
penyampaian informasi perubahan harga karet tidak dapat dilakukan kepada petani.

Dengan adanya permasalahan pada PT. Bumi Beliti Abadi, penulis mencoba untuk membuat sistem yang baru yang diharapkan dapat membantu proses pengelolahan data karet. Sistem yang baru akan dibangun dengan aplikasi berbasis Web Mobile, yang mana dengan aplikasi ini diharapkan dapat mengatasi permasalahan pengelolahan data karet yang selama ini terjadi di PT. Bumi Beliti Abadi yang dinilai lambat. Sistem ini akan dapat melakukan proses pendataan yang lebih baik karena dapat mempercepat proses pendataan karet, hasil dari pengelolaan data akan tersimpan dalam sebuah database sistem. Serta hasil akhir dari proses pengelolaan data akan terdapat menu laporan hasil penjualan karet berdasarkan priode waktu tertentu.

\section{TINJAUAN PUSTAKA}

\subsection{Sistem Informasi}

Sistem informasi merupakan suatu komponen yang saling berhubungan dan bekerjasama dalam mengumpulkan, memproses, menyimpan dan mendistribusikan sebuah informasi untuk mendukung pengambilan keputusan dalam suatu organisasi sehingga menghasilkan data yang akurat dan terpercaya [6].

\subsection{Karet}

Tanaman karet merupakan salah satu komoditas ekspor perkebunan andalan Indonesia. Lateks adalah getah segar berbentuk cair dan berwarna putih susu yang keluar dari sadapan pohon karet Hevea brasiliensis. Gumpalan Karet adalah lateks yang mengalami proses penggumpalan melalui cara alami (pra-koagulasi) maupun penambahan bahan penggumpal dalam mangkuk sadap, bak atau wadah lain. Bahan olah karet yang selanjutnya disebut BOKAR adalah lateks dan atau gumpalan yang dihasilkan pekebun kemudian diolah lebih lanjut secara sederhana sehingga menjadi bentuk lain yang bersifat lebih tahan untuk disimpan serta tidak tercampur dengan kontaminan [5].

\subsection{Web Mobile}

Web mobile merupakan sebuah website yang dapat memberikan informasi melalui internet dengan fasilitas yang telah disediakan serta dapat memberikan dan mempercepat penyampaian informasi yang berguna bagi masyarakat [7]. Web mobile adalah aplikasi penyampaian informasi yang dibngun dengan menggunakan bahasa pemrograman PHP dan database MySQLI dan dapat membantu dalam penyebaran informasi secara akurat dan mudah diakses [8].

\section{METODOLOGI PENELITIAN}

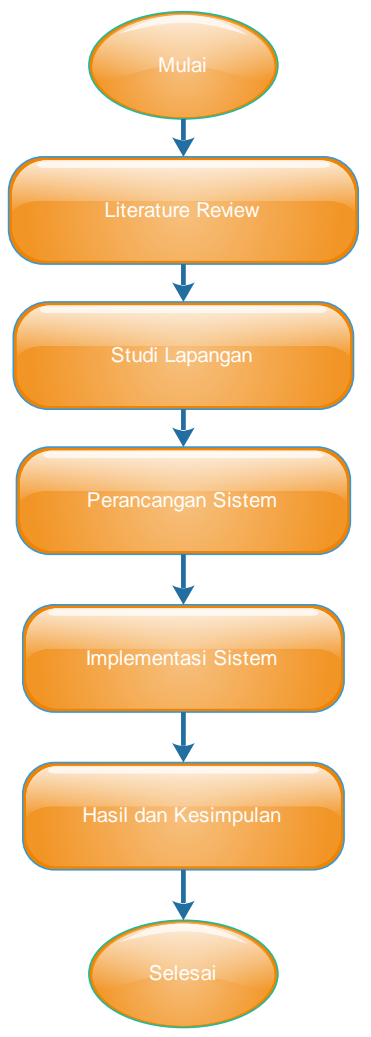

Gambar 1 Kerangka Berpikir Sumber : Hasil Penelitian

Dalam menyusn penelitian ini penulis membuat kerangka berpikir, dimana kerangka berpikir dalam penelitian ini 
dimulai dari literature review, literature review dalam penelitian penulis menggunakan jurnal-jurnal yang relevan dengan topik penelitian, selanjutnya penulis melakukan studi lapangan di PT Bumi Beliti Abadi untuk mendapatkan permasalahanpermasalahan yang ada untuk dievaluasi. Tahapan selanjutnya penulis melakukan perancangan sistem dengan menggunakan metode pengembangan sistem waterfall, tahapan selanjutnya setelah perancangan sistem penulis melakukan implementasi sistem dengan cara melakukan pengujian sistem menggunakan metode pengujian black box sehingga dapat menghasilkan kesimpulan dari penelitian ini.

Dalam peneltian ini penulis menggunakan metode pengembangan sistem SDLC waterfall. Metode SDLC Waterfal merupakan salah satu metode yang mempunyai ciri khas bahwa pengerjaan setiap fase harus dikerjakan terlebih dahulu sebelum melanjutkan ke fase berikutnya. Dengan demikian hasilnya akan fokus terhadap masing-masing fase sehingga pengerjaan dilakukan secara maksimal karena tidak adanya pengerjaan secara paralel [9].

Adapun kelebihan menggunakan metode waterfall diantaranya:

1 Urutan proses pengerjaan menggunakan metode ini menjadi lebih teratur dari satu tahap ke tahap yang selanjutnya.

2 Dari sisi user juga lebih menguntungkan karena dapat merencanakan dan menyiapkan seluruh kebutuhan data dan proses yang akan diperlukan

3 Jadwal menjadi lebih menentu karena jadwal setiap proses dapat ditentukan secara pasti. Sehingga dapat dilihat jelas target penyelesaian pengembangan program. Dengan adanya urutan yang pasti, dapat dilihat pula progress untuk setiap tahap secara pasti.

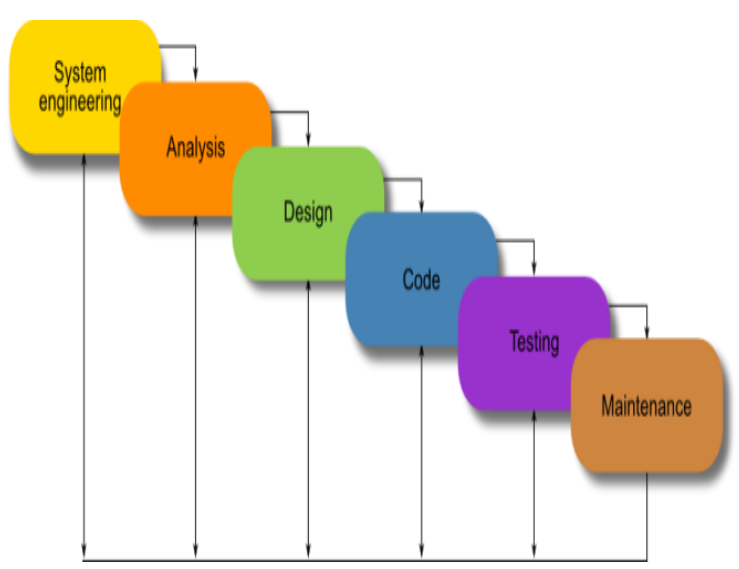

Gambar 2 Metodologi Waterfall Sumber : [9]

Berikut ini langkah-langkah proses pengembangan sistem menggunakan metode waterfall :

a. Analisis Kebutuhan

Proses pengumpulan kebutuhan

dilakukan secara intensif untuk menspesifikasikan kebutuhan perangkat lunak seperti apa yang dibutuhkan oleh user. Spesifikasi kebutuhan perangkat lunak pada tahap ini perlu di dokumentasikan.

b. Desain Sistem

Desain perangkat lunak adalah proses multi langkah yang fokus pada desain pembuatan program perangkat lunak termasuk struktur data, arsitektur perangkat lunak, representasi antar muka, dan prosedur pengodean.

c. Penulisan kode program

Desain harus di traslasikan ke dalam program perangkat lunak. Hasil dari tahap ini adalah program komputer sesuai dengan desain yang telah dibuat pada tahap desain.

d. Pengujian Program

Pengujian fokus pada perangkat lunak secara dari segi logik dan fungsional dan memastikan bahwa semua bagian sudah diuji. Hal ini dilakukan untuk meminimalisir kesalahan (error) dan memastikan 
keluaran yang dihasilkan sesuai yang diinginkan.

e. Penerapan (Implementasi)

\section{HASIL DAN PEMBAHASAN}

Sistem Informasi Pengelolahan Karet Pada PT. Bumi Beliti Abadi yang telah dibuat pada penelitian ini merupakan aplikasi yang dapat digunakan sebagai alat bantu untuk melakukan pengolahan data harga karet, penjualan, pembelian, produksi
Setelah melakukan analisa, design, pengkodean dan Pengujian maka sistem akan di implementasi

\subsection{Tampilan Sistem}

1 Tampilan Halaman Awal Sistem

Berikut ini gambar halaman Awal Sistem dapat dilihat pada gambar 3, halaman awal sistem adalah halaman yang akan pertama kali tampil ketika diakses.

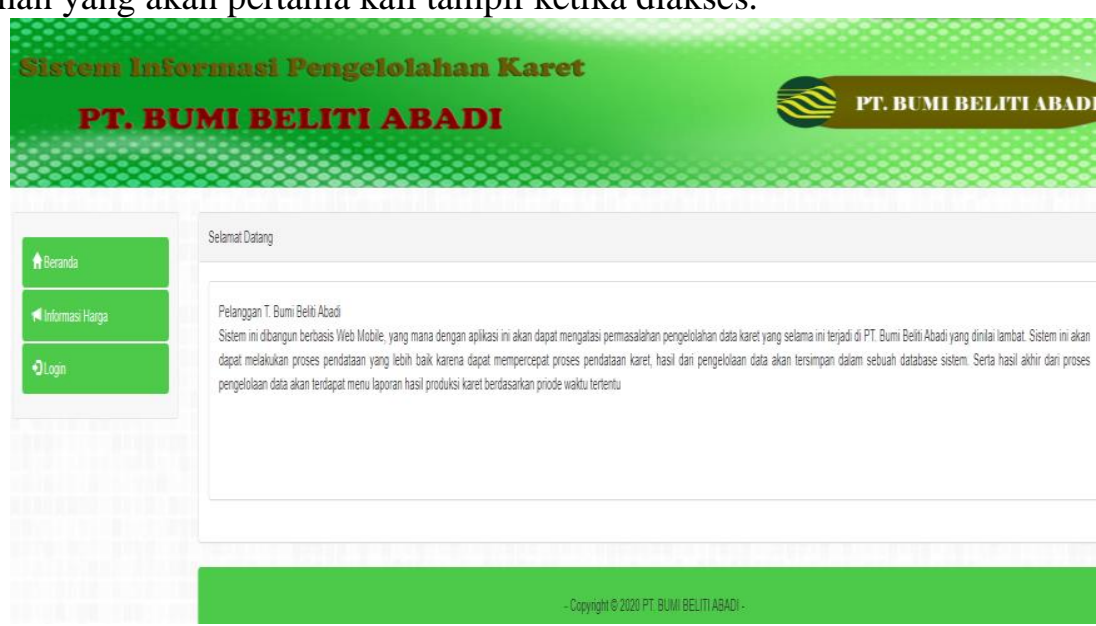

Gambar 3 Tampilan Halaman Awal Sistem

Sumber Data : Hasil Penelitian

2 Tampilan Halaman Login Sistem

Berikut ini gambar halaman login Sistem dapat dilihat pada gambar 4, halaman login sistem adalah halaman yang digunakan untuk melakukan pengolahan data dengan cara harus login terlebih dahulu dengan menggunakan username dan password yang telah disediakan.

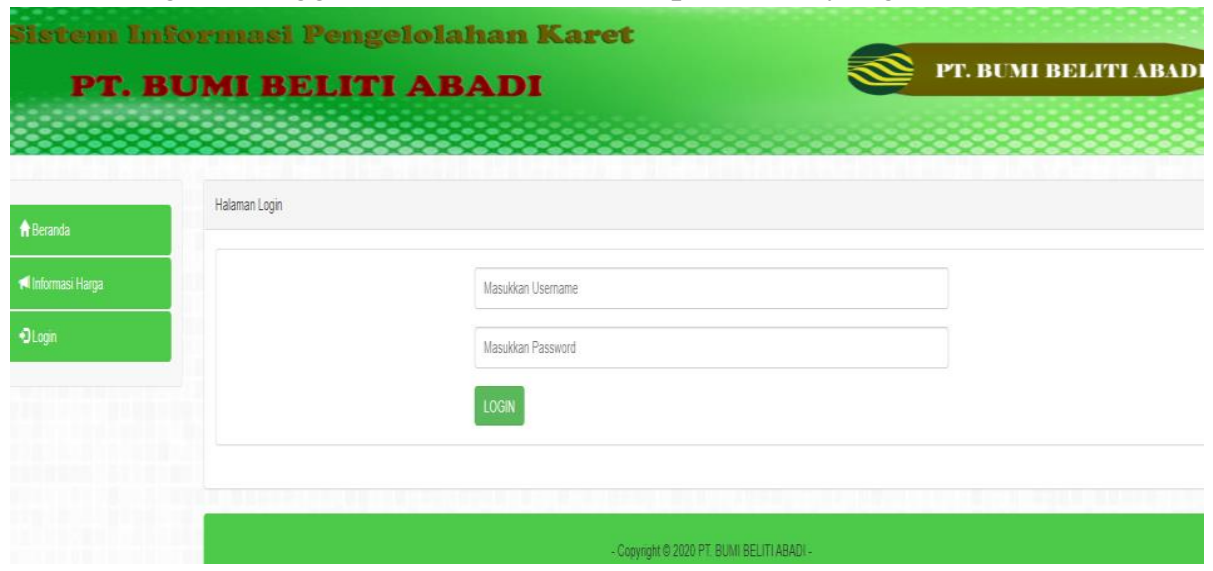

Gambar 4 Tampilan Halaman Login Sistem

Sumber Data : Hasil Penelitian 
3 Tampilan Halaman Informasi Harga

Berikut ini gambar halaman Informasi Harga dapat dilihat pada gambar 5, halaman informasi harga merupakan halaman yang dapat digunakan oleh petani untuk melihat daftar harga secara realtime dan update setiap hari nya.

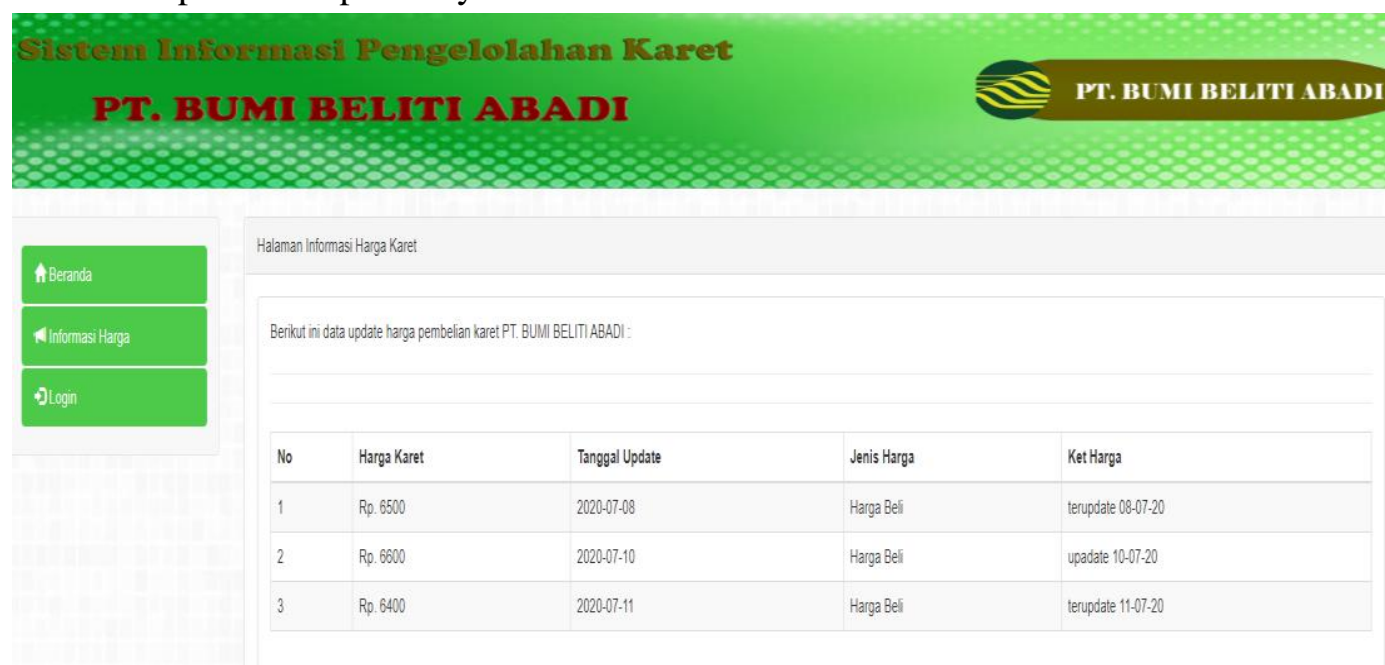

Gambar 5 Tampilan Halaman Informasi Harga Sumber Data : Hasil Penelitian

4 Tampilan Halaman Kelola Data Harga Karet

Berikut ini gambar halaman data harga karet dapat dilihat pada gambar 6 dan gambar 7, halaman kelola data harga karet merupakan halaman yang digunakan untuk melakukan pengolahan data harga karet.
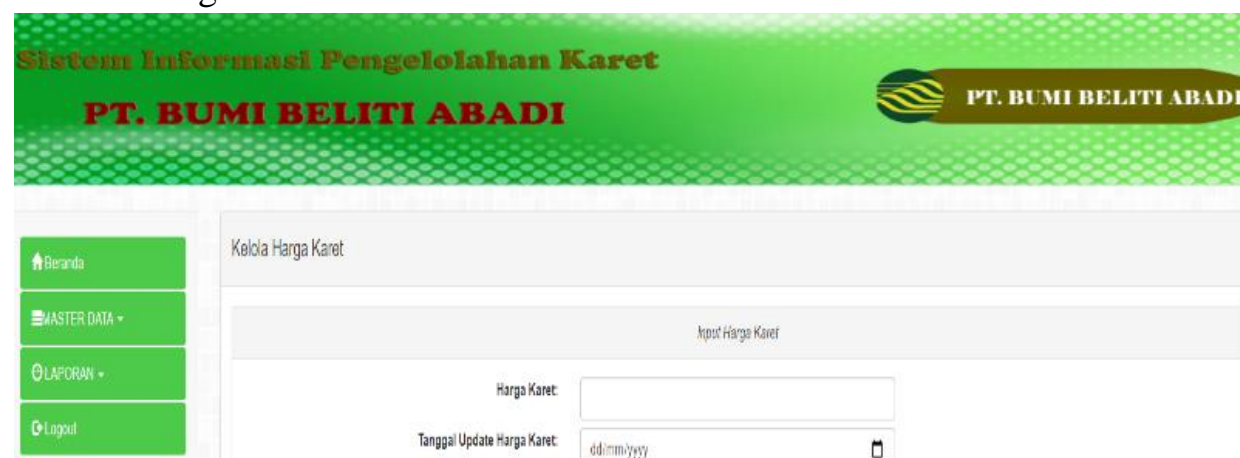

Kelcia Harga Karet

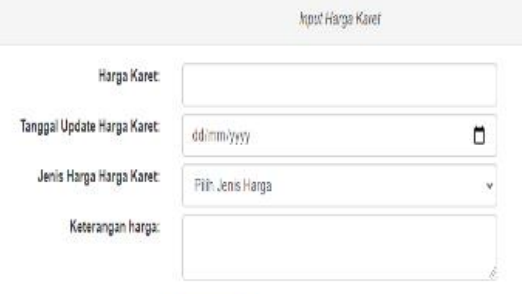

Gambar 6 Tampilan Halaman Input Data Harga Karet Sumber Data : Hasil Penelitian 


\begin{tabular}{|c|c|c|c|c|c|c|}
\hline \multicolumn{7}{|c|}{ Data Harga Karet } \\
\hline No & Harga Karet & Tanggal Update & Jenis Harga & Ket Harga & Opsi & \\
\hline 1 & Rp. 6500 & 2020.07 .08 & Harga Beli & terupdate 08-07.20 & Haps & Upotate \\
\hline 2 & Rp. 8000 & 2020.07 .09 & Harga Jual & terupdate $09 .-07.20$ & Hequs & Upotet \\
\hline 3 & Rp. 6600 & $2020-07 \cdot 10$ & Harga Beli & upadate 10.07-20 & Hequs & Uposte \\
\hline 4 & Rp. 8100 & 2020.07 .14 & Harga Jual & terupdate 14.07-20 & Haps & uposte \\
\hline 5 & Rp. 6400 & 2020-07-11 & Harga Beli & terupdate 11-07-20 & Haws & Updote \\
\hline
\end{tabular}

Gambar 7 Tampilan Halaman Data Harga Karet Sumber Data : Hasil Penelitian

5 Tampilan Kelola Data Pembelian

Berikut ini gambar halaman data pembelian dapat dilihat pada gambar 8 dan gambar 9, halaman kelola data pembelian merupakan halaman yang digunakan untuk melakukan pengolahan data pembelian.
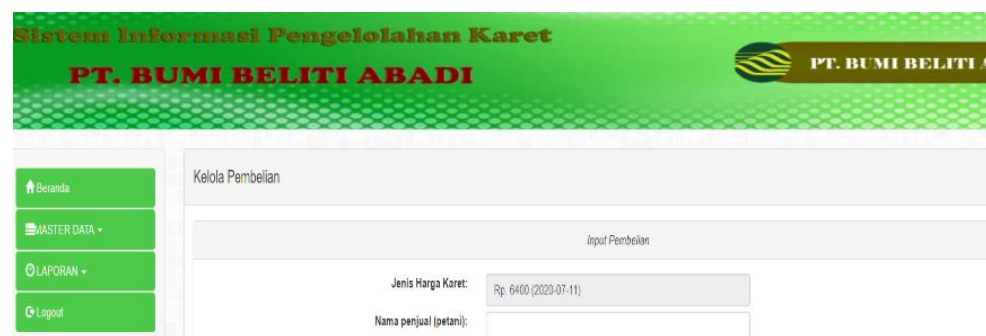

Kelola Pembelian

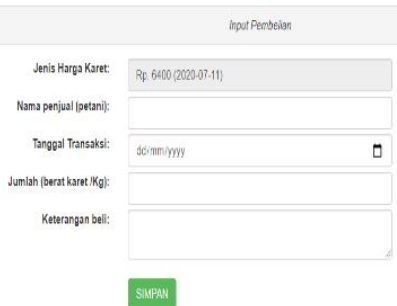

Gambar 8 Tampilan Halaman Input Data Pembelian Sumber Data : Hasil Penelitian

\begin{tabular}{|c|c|c|c|c|c|c|c|c|}
\hline \multicolumn{9}{|c|}{ Data Pembelian } \\
\hline No & Harga Karet & Nama Penjual & Tanggal Transaksi & jumlan (beratkaret $/ g g)$ & Harga Total & Ket Pembelian & Opsi & \\
\hline 1 & $\begin{array}{l}\text { Rp. } 66000 \\
\text { (Upoded : 2020-07.10) }\end{array}$ & and & $2022-07 \cdot 10$ & $5 \mathrm{Kg}$ & Re 33000 & okee selesai & Hats & wate \\
\hline 2 & $\begin{array}{l}\text { Rp. 6400 } \\
\text { (Updated : 2020-07-11) }\end{array}$ & wanto & $2022-07 \cdot 11$ & $120 \mathrm{Kg}$ & $\operatorname{Rp} 768000$ & selesai & Hows & wotate \\
\hline 3 & $\begin{array}{l}\text { Rp. 6400 } \\
\text { (Updated: 2020-07.11) }\end{array}$ & andara & $2020-07-11$ & $1600 \mathrm{Kg}$ & Rp. 1024000 & oke selesai & Hows & lostit \\
\hline 4 & $\begin{array}{l}\text { Rp. 6400 } \\
\text { (Updated: 2020-07-11) }\end{array}$ & abodl & $2020-07 \cdot 12$ & $68 \mathrm{Kg}$ & Rp. 435200 & oke & Haxs & wate \\
\hline
\end{tabular}

Gambar 9 Tampilan Halaman Data Pembelian Sumber Data : Hasil Penelitian 
6 Tampilan Halaman Laporan

Berikut ini gambar halaman laporan pada sistem dapat dilihat pada gambar 10 dan gambar 11 dan gambar 12, halaman laporan merupakan halaman hasil keluaran dari pengolahan data telah dilakukan dalam bentuk grafik.

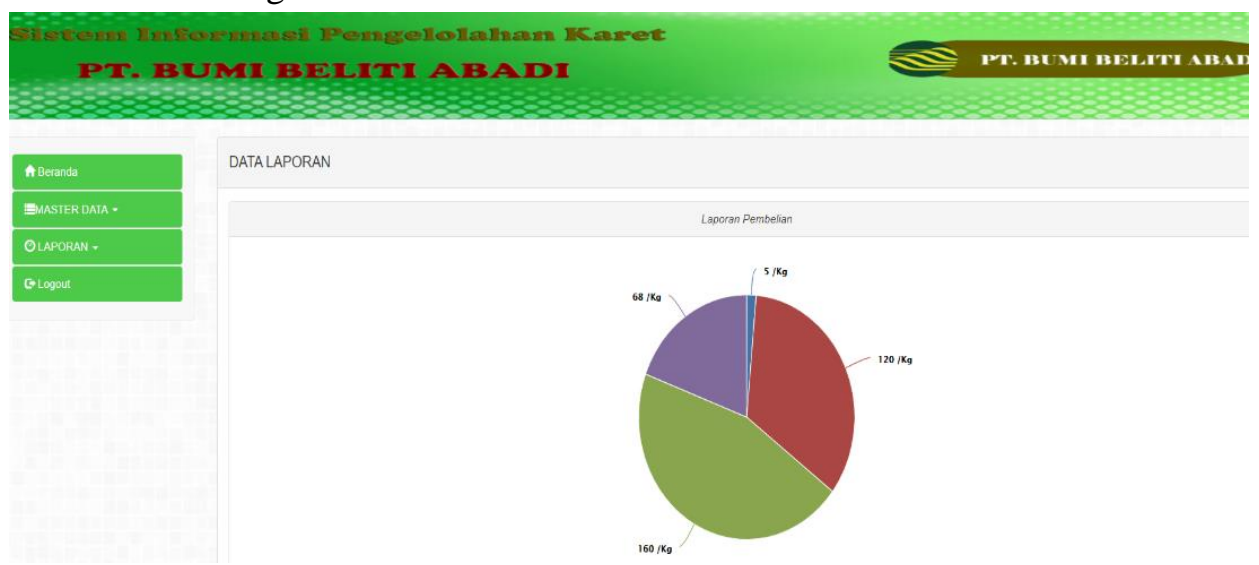

Gambar 10 Tampilan Halaman Laporan Pembelian Sumber Data : Hasil Penelitian

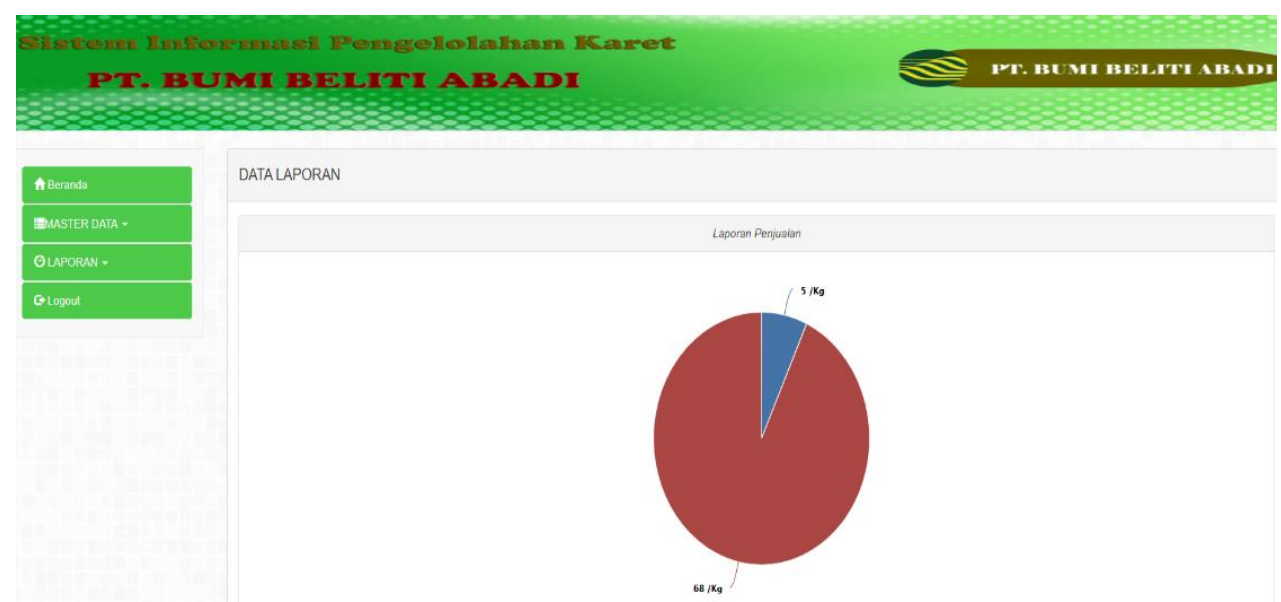

Gambar 11 Tampilan Halaman Laporan Penjualan Sumber Data : Hasil Penelitian

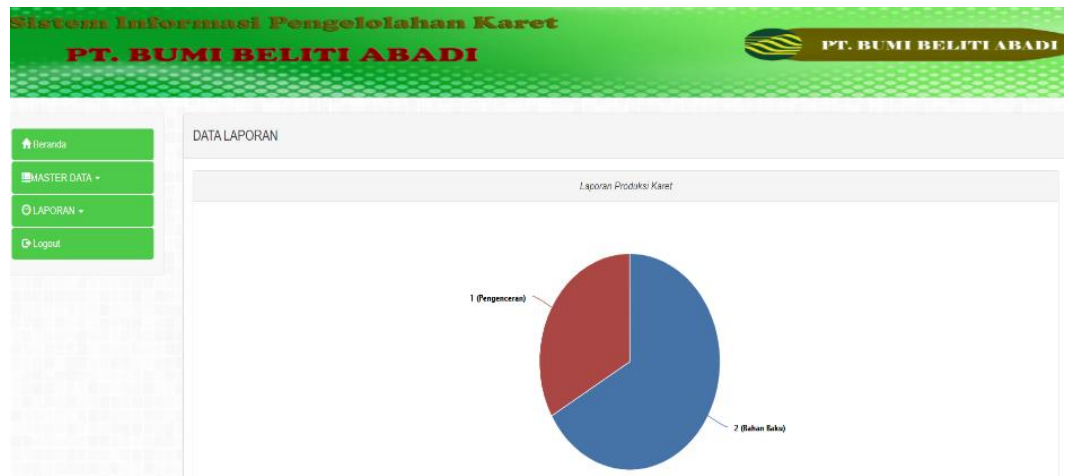

Gambar 12 Tampilan Halaman Laporan Penjualan Karet Sumber Data : Hasil Penelitian 


\subsection{Pengujian Sistem}

Berikut beberapa kasus pengujian dan hasil dari pengujian Sistem Informasi Pengelolahan

Karet Pada PT. Bumi Beliti Abadi, yang akan ditampilkan pada Tabel 1.

Tabel 1 Skenario dan Hasil Pengujian Sistem

\begin{tabular}{|c|c|c|c|}
\hline Requirment & Skenario uji & Hasil yang diharapkan & Hasil pengujian \\
\hline \multirow[b]{2}{*}{ Login Sistem } & $\begin{array}{l}\text { Login Sistem } \\
\text { (jika benar) }\end{array}$ & Tampil Ke halaman utama Sistem & Valid \\
\hline & $\begin{array}{l}\text { Login Sistem } \\
\text { (jika salah) }\end{array}$ & $\begin{array}{c}\text { Tampil konfirmasi login gagal dan } \\
\text { tampilan login Sistem }\end{array}$ & Valid \\
\hline \multirow[b]{2}{*}{ Input data Harga karet } & $\begin{array}{c}\text { Input data Harga karet } \\
\text { (jika berhasil) }\end{array}$ & $\begin{array}{c}\text { Data tersimpan dalam database dan } \\
\text { kembali kehalaman home }\end{array}$ & Valid \\
\hline & $\begin{array}{l}\text { Input Harga karet } \\
\text { (jika gagal) }\end{array}$ & $\begin{array}{l}\text { Data tidak tersimpan dan tampil } \\
\text { gagal input }\end{array}$ & Valid \\
\hline \multirow[b]{2}{*}{ Edit data Harga karet } & $\begin{array}{l}\text { Edit data Harga karet } \\
\text { ( jika berhasil) }\end{array}$ & $\begin{array}{c}\text { data Harga karet di database terEdit } \\
\text { dan kembali kehalaman home }\end{array}$ & Valid \\
\hline & $\begin{array}{l}\text { Edit data Harga karet } \\
\text { (jika tidak berhasil) }\end{array}$ & $\begin{array}{c}\text { data Harga karet di database tidak } \\
\text { terEdit dan tampil gagal Edit }\end{array}$ & Valid \\
\hline \multirow{2}{*}{ Hapus data Harga karet } & $\begin{array}{l}\text { Hapus data Harga karet } \\
\text { ( jika berhasil ) }\end{array}$ & $\begin{array}{l}\text { data Harga karet di } \\
\text { databaseTerhapus, tampil popup } \\
\text { data berhasil dihapus dan kembali } \\
\text { kehalaman home }\end{array}$ & Valid \\
\hline & $\begin{array}{l}\text { Hapus Harga karet } \\
\text { ( jika tidak berhasil ) }\end{array}$ & $\begin{array}{c}\text { data Harga karet di database tidak } \\
\text { terhapus dan tampil popup gagal } \\
\text { hapus data }\end{array}$ & Valid \\
\hline \multirow[t]{2}{*}{ Lihat data Harga karet } & $\begin{array}{l}\text { Menampilkan Harga karet } \\
\text { (jika benar) }\end{array}$ & $\begin{array}{c}\text { Menampilkan keseluruhan data } \\
\text { Harga karet }\end{array}$ & Valid \\
\hline & $\begin{array}{l}\text { Menampilkan Harga karet } \\
\text { (jika gagal) }\end{array}$ & $\begin{array}{l}\text { Tidak menampilkan data Harga } \\
\text { karet atau kembali ke home }\end{array}$ & Valid \\
\hline \multirow[b]{2}{*}{ Input data Pembelian } & $\begin{array}{l}\text { Input data Pembelian } \\
\text { (jika berhasil) }\end{array}$ & $\begin{array}{c}\text { Data tersimpan dalam database dan } \\
\text { kembali kehalaman home }\end{array}$ & Valid \\
\hline & $\begin{array}{l}\text { Input data Pembelian } \\
\text { (jika gagal) }\end{array}$ & $\begin{array}{c}\text { Data tidak tersimpan dan tampil } \\
\text { keterangan gagal input }\end{array}$ & Valid \\
\hline \multirow[b]{2}{*}{ Edit data Pembelian } & $\begin{array}{l}\text { Edit data Pembelian } \\
\text { ( jika berhasil) }\end{array}$ & $\begin{array}{c}\text { data Pembelian di database terEdit } \\
\text { dan kembali kehalaman home }\end{array}$ & Valid \\
\hline & $\begin{array}{l}\text { Edit data Pembelian } \\
\text { (jika tidak berhasil) }\end{array}$ & $\begin{array}{l}\text { data Pembelian di database tidak } \\
\text { terEdit dan tampil gagal Edit }\end{array}$ & Valid \\
\hline \multirow{2}{*}{ Hapus data Pembelian } & $\begin{array}{l}\text { Hapus data Pembelian } \\
\text { ( jika berhasil ) }\end{array}$ & $\begin{array}{l}\text { data Pembelian di } \\
\text { databaseTerhapus, tampil popup } \\
\text { data berhasil dihapus dan kembali } \\
\text { kehalaman home }\end{array}$ & Valid \\
\hline & $\begin{array}{l}\text { Hapus Pembelian } \\
\text { ( jika tidak berhasil ) }\end{array}$ & $\begin{array}{c}\text { data Pembelian di database tidak } \\
\text { terhapus dan tampil popup gagal } \\
\text { hapus data }\end{array}$ & Valid \\
\hline \multirow[t]{2}{*}{ Lihat data Pembelian } & $\begin{array}{l}\text { Menampilkan Pembelian } \\
\text { (jika benar) }\end{array}$ & $\begin{array}{c}\text { Menampilkan keseluruhan data } \\
\text { Pembelian }\end{array}$ & Valid \\
\hline & $\begin{array}{c}\text { Menampilkan Pembelian } \\
\text { (jika gagal) }\end{array}$ & $\begin{array}{c}\text { Tidak menampilkan data Pembelian } \\
\text { atau kembali ke home }\end{array}$ & Valid \\
\hline \multirow[b]{2}{*}{ Input data Penjualan } & $\begin{array}{c}\text { Input data Penjualan } \\
\text { (jika berhasil) }\end{array}$ & $\begin{array}{c}\text { Data tersimpan dalam database dan } \\
\text { kembali kehalaman home }\end{array}$ & Valid \\
\hline & $\begin{array}{c}\text { Input data Penjualan } \\
\text { (jika gagal) }\end{array}$ & $\begin{array}{c}\text { Data tidak tersimpan dan tampil } \\
\text { keterangan gagal input }\end{array}$ & Valid \\
\hline \multirow[b]{2}{*}{ Edit data Penjualan } & $\begin{array}{l}\text { Edit data Penjualan } \\
\text { ( jika berhasil) }\end{array}$ & $\begin{array}{c}\text { data Penjualan di database terEdit } \\
\text { dan kembali kehalaman home }\end{array}$ & Valid \\
\hline & $\begin{array}{l}\text { Edit data Penjualan } \\
\text { (jika tidak berhasil) }\end{array}$ & $\begin{array}{c}\text { data Penjualan di database tidak } \\
\text { terEdit dan tampil gagal Edit }\end{array}$ & Valid \\
\hline \multirow{2}{*}{ Hapus data Penjualan } & $\begin{array}{l}\text { Hapus data Penjualan } \\
\text { ( jika berhasil ) }\end{array}$ & $\begin{array}{l}\text { data Penjualan di } \\
\text { databaseTerhapus, tampil popup } \\
\text { data berhasil dihapus dan kembali } \\
\text { kehalaman home }\end{array}$ & Valid \\
\hline & $\begin{array}{c}\text { Hapus Penjualan } \\
\text { ( jika tidak berhasil ) }\end{array}$ & $\begin{array}{l}\text { data Penjualan di database tidak } \\
\text { terhapus dan tampil popup gagal } \\
\text { hapus data }\end{array}$ & Valid \\
\hline
\end{tabular}




\begin{tabular}{|c|c|c|c|}
\hline \multirow[t]{2}{*}{ Lihat data Penjualan } & $\begin{array}{l}\text { Menampilkan Penjualan } \\
\text { (jika benar) }\end{array}$ & $\begin{array}{l}\text { Menampilkan keseluruhan data } \\
\text { Penjualan }\end{array}$ & Valid \\
\hline & $\begin{array}{l}\text { Menampilkan Penjualan } \\
\text { (jika gagal) }\end{array}$ & $\begin{array}{c}\text { Tidak menampilkan data Penjualan } \\
\text { atau kembali ke home }\end{array}$ & Valid \\
\hline \multirow[b]{2}{*}{ Input data Produksi karet } & $\begin{array}{l}\text { Input data Produksi karet } \\
\text { (jika berhasil) }\end{array}$ & $\begin{array}{c}\text { Data tersimpan dalam database dan } \\
\text { kembali kehalaman home }\end{array}$ & Valid \\
\hline & $\begin{array}{l}\text { Input Produksi karet } \\
\text { (jika gagal) }\end{array}$ & $\begin{array}{l}\text { Data tidak tersimpan dan tampil } \\
\text { gagal input }\end{array}$ & Valid \\
\hline \multirow{2}{*}{ Edit data Produksi karet } & $\begin{array}{l}\text { Edit data Produksi karet } \\
\text { ( jika berhasil) }\end{array}$ & $\begin{array}{c}\text { data Produksi karet di database } \\
\text { terEdit dan kembali kehalaman } \\
\text { home }\end{array}$ & Valid \\
\hline & $\begin{array}{l}\text { Edit data Produksi karet } \\
\text { (jika tidak berhasil) }\end{array}$ & $\begin{array}{l}\text { data Produksi karet di database } \\
\text { tidak terEdit dan tampil gagal Edit }\end{array}$ & Valid \\
\hline \multirow[b]{2}{*}{ Hapus data Produksi karet } & $\begin{array}{l}\text { Hapus data Produksi karet } \\
\text { ( jika berhasil ) }\end{array}$ & $\begin{array}{c}\text { data Produksi karet di } \\
\text { databaseTerhapus, tampil popup } \\
\text { data berhasil dihapus }\end{array}$ & Valid \\
\hline & $\begin{array}{l}\text { Hapus Produksi karet } \\
\text { ( jika tidak berhasil ) }\end{array}$ & $\begin{array}{l}\text { data Produksi karet di database } \\
\text { tidak terhapus dan tampil popup } \\
\text { gagal hapus data }\end{array}$ & Valid \\
\hline \multirow[t]{2}{*}{ Lihat data Produksi karet } & $\begin{array}{c}\text { Menampilkan Produksi } \\
\text { karet } \\
\text { (jika benar) } \\
\end{array}$ & $\begin{array}{l}\text { Menampilkan keseluruhan data } \\
\text { Produksi karet }\end{array}$ & Valid \\
\hline & $\begin{array}{c}\text { Menampilkan Produksi } \\
\text { karet } \\
\text { (jika gagal) }\end{array}$ & $\begin{array}{l}\text { Tidak menampilkan data Produksi } \\
\text { karet atau kembali ke home }\end{array}$ & Valid \\
\hline \multirow[t]{2}{*}{$\begin{array}{c}\text { Tampil data laporan } \\
\text { penjualan, pembelian data } \\
\text { produksi karet }\end{array}$} & $\begin{array}{c}\text { Menampilkan Laporan data } \\
\text { laporan penjualan, } \\
\text { pembelian data produksi } \\
\text { karet } \\
\text { (jika benar) } \\
\end{array}$ & $\begin{array}{l}\text { Menampilkan keseluruhan data data } \\
\text { laporan penjualan, pembelian data } \\
\text { produksi karet }\end{array}$ & Valid \\
\hline & $\begin{array}{c}\text { Menampilkan Laporan data } \\
\text { laporan penjualan, pembelian } \\
\text { data produksi karet } \\
\text { (jika gagal) }\end{array}$ & $\begin{array}{c}\text { Tidak data laporan penjualan, } \\
\text { pembelian data produksi karet atau } \\
\text { kembali ke home }\end{array}$ & Valid \\
\hline \multirow[t]{2}{*}{ Logout sistem } & $\begin{array}{l}\text { logout Sistem } \\
\text { (jika berhasil) }\end{array}$ & $\begin{array}{c}\text { Tampil Ke halaman halaman login } \\
\text { Sistem }\end{array}$ & Valid \\
\hline & logout Sistem (jika gagal) & Tampil konfirmasi logout gagal & Valid \\
\hline
\end{tabular}

Sumber Data : Hasil Penelitian

\section{KESIMPULAN}

Dari hasil dan pembahasan pada bab sebelumnya maka dapat disimpulkan sebagai berikut:

1. Sistem informasi yang dihasilkan dapat memberikan melakukan pengolahan data harga karet, penjualan, pembelian dan data produksi karet.

2. Sistem informasi yang dibangun memiliki tiga aktor yaitu admin yang dapat melakukan pengolahan keseluruhan data sistem, pimpinan yang dapat menampilkan laporan sistem serta petani karet yang dapat menampilkan update harga karet.
3. Sistem informasi yang dibangun akan menghasilkan laporan dalam bentuk statistik dari data hasil pengolahan data penjualan, pembelian dan produksi karet

\section{SARAN}

Berdasarkan dari analisis dan perancangan sistem, maka dibuat saran sebagai berikut :

1. Memberbaiki interface sistem yang dapat ditampilkan di aplikasi android.

2. Memperbaiki proses pengolahan data produksi karet yang dapat dilakukan disetiap tahapan penjualan. 
3. Perlu adanya backup data, sehingga jika kehilanggan data sistem dapat sercara langsung melakukan recovery.

\section{DAFTAR PUSTAKA}

[1] E. R. Yulia and N. Nuris, "PERANCANGAN SISTEM INFORMASI PENJUALAN OBAT PADA KLINIK IBU MAS DEPOK," JUSIM (Jurnal Sist. Inf. Musirawas), vol. 3, no. 2, pp. 112 121, 2018, doi: $10.32767 /$ jusim.v3i2.339.

[2] O. Irnawati and I. Darwati, "RANCANG BANGUN PROGRAM PENGGAJIAN DIDUKUNG MODEL RAPID APPLICATION DEVELOPMENT," JUSIM (Jurnal Sist. Inf. Musirawas), vol. 4, no. 1, pp. 37-44, 2019, doi: 10.32767/jusim.v4i1.395.

[3] O. Lesva and A. Arif, "Sistem Informasi Wisata Purbakala Situs Megalithikum Kota Pagaralam, Sumatera Selatan," JUSIM (Jurnal Sist. Inf. Musirawas), vol. 5, no. 2, pp. 111-123, 2020, doi: 10.32767/jusim.v5i02.1034.

[4] A. Zulius and N. K. Daulay, "SISTEM INFORMASI GEOGRAFIS LOKASI WISATA KULINER PADA KOTA LUBUKLINGGAU BERBASIS ANDROID," JUSIM (Jurnal Sist. Inf. Musirwas), vol. 4, no. 2, pp. 109115, 2019.

[5] F. Rizki, M. I. Herdiansyah, and D. Antoni, "Model Optimasi Biaya Produksi Pada Jaringan Rantai Pasok Karet Rakyat Menggunakan Pemrograman Linier," vol. 5, no. April, pp. 447-459, 2021, doi: 10.30865/mib.v5i2.2805.

[6] T. Rahman, R. Kurniawan, and O. M. Sari, "Sistem Informasi Rekam Medis Pada Dinas Kesehatan Kabupaten Musirawas Berbasis Web Mobile," JUTIM (Jurnal Tek. Inform. Musirawas), vol. 5, no. 2, pp. 141-156, 2020, doi: 10.32767/jutim.v5i2.1139.
A. T. Hidayat, "Perancangan Sistem Informasi Dinas Pendapataan Pengelolaan Keuangan Aset Daerah Kabupaten Mura Tara Berbasis Web Mobile," JUSIM (Jurnal Sist. Inf. Musirawas), vol. 4, no. 1, pp. 27-36, 2019, doi: 10.32767/jusim.v4i1.418.

[8] J. Karman and D. Rahmanto, "Sistem Informasi Jadwal Kegiatan Majelis Ilmu Pada Kajian Linggau Mengaji Berbasis Web Mobile," JUSIM (Jurnal Sist. Inf. Musirawas), vol. 5, no. 1, pp. 55-68, 2020, doi: 10.32767/jusim.v5i01.837.

[9] W. Nugraha, M. Syarif, and W. S. Dharmawan, "Penerapan Metode Sdlc Waterfall Dalam Sistem Informasi Inventori Barang Berbasis Desktop," JUSIM (Jurnal Sist. Inf. Musirawas), vol. 3, no. 1, pp. 22-28, 2018, doi: 10.32767/jusim.v3i1.246. 